\title{
VALUE OF THE FIRM: INFLATION AND ROLE OF DIVIDEND DECISION MEDIATION
}

\author{
Sumani \\ Faculty of Business and Economic, Universitas Jember \\ sumanisumani69@gmail.com
}

Received: January, 2020; Accepted: March, 2020; Published: March, 2020

DOI: https://doi.org/10.24123/jmb.v19i1

\begin{abstract}
The objective of this study was to determine the effect of leverage, insider ownership, investment opportunity set (IOS) and inflation on dividend decision. Besides, to prove the effect of leverage, insider ownership, investment opportunity set (IOS) and inflation on firm value through the role of dividend decision mediation and to determine the direct effect of dividend policy on a value of the firm in the consumer goods industry sector. The analysis method used is path analysis with a sample of 38 companies on consumer goods industry sector, which listed on the IDX during the 2010-2018 period, so the panel data used are 342 data. The results showed that insider ownership and investment opportunity set (IOS) significantly influence dividend decision. However, leverage and inflation do not affect the dividend decision. Also, insider ownership and inflation have a significant effect on the value of the firm but leverage and investment opportunity sets (IOS) do not affect. Dividend decision affects the value of the firm; besides, dividend decision is proven to significantly play a role in mediating the influence of insider ownership and investment opportunity sets (IOS) on the value of the firm.
\end{abstract}

Keywords: Dividend decision, inflation, the value of the firm.

\begin{abstract}
Abstrak
Tujuan penelitian ini adalah untuk mengetahui pengaruh leverage, insider ownership, investment opportunity set (IOS) dan inflasi terhadap kebijakan dividen. Selain itu, untuk membuktikan pengaruh leverage, insider ownership, investment opportunity set (IOS) dan inflasi terhadap nilai perusahaan melalui peran mediasi kebijakan deviden serta untuk mengetahui pengaruh langsung kebijakan dividen terhadap nilai perusahaan sektor industri barang konsumsi. Metode analisis yang digunakan adalah path analysis dengan jumlah sampel 38 perusahaan sektor industri barang konsumsi yang terdaftar di BEI selama periode 2010-2018, sehingga data panel yang digunakan sebanyak 342 data. Hasil penelitian menunjukkan bahwa insider ownership dan investment opportunity set (IOS) berpengaruh signifikan terhadap kebijakan dividen. Namun, leverage dan inflasi tidak berpengaruh terhadap kebijakan deviden. Selain itu, insider ownership dan inflasi berpengaruh signifikan terhadap nilai perusahaan, namun leverage dan investment opportunity set (IOS) tidak berpengaruh Kebijakan dividen berpengaruh terhadap nilai perusahaan, selain itu, kebijakan dividen terbukti secara signifikan berperan dalam memediasi pengaruh insider ownership dan investment opportunity set (IOS) terhadap nilai perusahaan.
\end{abstract}

Kata Kunci: kebijakan dividen, inflasi, nilai perusahaan. 


\section{INTRODUCTION}

Dividend decision, until now still a matter of debate, namely whether the dividend is paid from income (net income) or retained for future investment. Also, whether the dividend is paid in the form of cash dividends or stock dividends. Some empirical studies state that dividend payment is irrelevant (dividend irrelevance theory) on company performance because the value of the company is not determined by the size of the dividend pay-out ratio but is determined by net income before taxes and company risk. However, several other empirical studies state that dividend payments are relevant to value of the company. Theories that explain the role of Dividend decision on relative corporate value are many, namely theory: Irrelevance Theory, The Bird in the Hand Theory, Tax Preference Theory, Signalling Theory, and Agency Theory. However, some of these theories use different approaches and assumptions, giving rise to gap theory (Allen et al., 2000; Amidu, 2007; Baker \& Wurger, 2004; Bhattacharya, 1979; Boyd \& Jagannathan, 1994; Budagaga, 2017; Fama \& Babiak, 1968; Gordon, 1961; Lintner, 1956; Litzenberger \& Ramaswamy, 1982; Miller \& Modligiani, 1961; Oliver et al., 2016; Petitt, 1977; Rozeff, 1982; Supriyanah \& Ghoniyah, 2015; Walter, 1963; Watts, 1973).

Value of the firm is a specific condition that has been achieved by a company. The purpose of corporate financial management is to maximize the wealth of shareholders. It means the value of the company will be increasing, which is a measure of objective value by the public and an orientation to the survival of the company. Factors that influence the value of the company are company size, company growth, company uniqueness, ownership structure, debt policy (leverage), Dividend decision, asset value, value fluctuations and capital market conditions (Harmono, 2014). The dividend is a permanent payment for capital given by shareholders or company owners (Syamsuddin, 2011). Dividend decision is the percentage of profit paid to shareholders in the form of cash dividends, maintaining dividend stability from time to time, distribution of stock dividends and share buybacks (Harmono, 2014). Factors that can influence Dividend decision are investment opportunities and alternative sources of capital. Sources of corporate capital consist of the sale of new shares and capital from debt, managerial ownership (insider ownership), institutional ownership (institutional ownership), and collateralized assets (Brigham \& Houston, 2011).

The process of maximizing the value of a company often creates conflicts of interest between managers and shareholders, which is often called the agency problem. It is uncommon for management, the company manager, to have other goals and interests that conflict with the company's main objectives. Manager's interests that conflict with company goals can jeopardize the survival and decrease the value of the company. Conflicts between managers and shareholders can be minimized by a supervisory mechanism that can align the interests of the parties, but also incur agency costs. There are several alternatives to reduce agency costs, one of which is managerial ownership/insider ownership (Haruman, 2008). According to Morck et al. (1989) in (Sofyaningsih \& Hardiningsih, 2011), the interests of managers and shareholders can be harmonized if the manager has a larger share of the company. The potential for agency conflicts to decline through dividend payments can affect the low agency cost incurred by shareholders (Kighir et al., 2015). In addition to insider ownership, funding policies (leverage), are reflected in Debt to Equity Ratio (DER), as well as forming dividend and corporate value policies. According to Al Najjar (2012), the higher debt causes the burden on companies to become significant because of the burden of debt costs that must be borne. The higher the debt will cause the company's priority to pay dividends will be smaller because the company's debt costs reduce the 
company's profits.

Investment opportunities are interpreted as a combination of asset-in-place and investment choices in the future with a positive net present value. Myers (1977) introduced IOS concerning achieving corporate goals, where the value of the company formed through the indicators of the stock market value is also strongly influenced by investment opportunities. Fidhayatin \& Dewi (2012) also emphasized that the component of a value of the firm and Dividend decision are the result of future investment choices and are expected to obtain higher returns, this is meant by the investment opportunity set (IOS).Of course, macroeconomic variables, such as inflation will also have an impact on Dividend decision and value of the firm. According to Munthe \& Hotmauli (2018) with the constant rate of inflation, capital costs, labour costs, and raw material costs will increase unexpectedly so the company will decide to increase the selling price of its products to consumers. This condition also results in a decrease in purchasing power or commonly referred to as a decrease in purchasing power of money, causing companies to experience a decline in profits and financial performance or even losses (Tandelilin, 2010).

By looking at this phenomenon, of course, the issue of dividend decision is an essential concern of the company in optimizing the value of the company, especially in economic conditions that are full of uncertainty as it is today. In a volatile global economy, Consumer Goods or sectors that provide domestic needs can still be stable. Learning from experience, in the 2008 financial crisis in the US, the sectors that could still get profits were the consumption and retail. In Indonesia, in 2011, the Consumer Goods sector increased its share value by $17.61 \%$, and the increase continued until 2011 (Kontan.co.id., 2012). During 2017, the consumer sector index has recorded an increase of 53.81 points, up $3.89 \%$ towards the level of $2,414.71$. The increase in the index of the consumer goods industry beats the index of the plantation, mining, property, financial industry and trade, services and investment sectors (Bisnis.com, 2017). Based on the news in Business Indonesia magazine, 100 Excellent GrowthCompany Ranks, the consumer goods industry is expected to rise in 2019. This condition is in line with the increasing consumption and disbursement of funds to the public in the political year, with presidential and legislative elections being held simultaneously in April 2019. Aid has increased, transfers to the regions as well as village funds have been poured slowly. Household consumption is projected to grow again in 2019 to around 5.2\%. This consumption is still the backbone of gross domestic product (GDP), with contributions reaching $56.01 \%$. The objective of this study was to determine the effect of leverage, insider ownership, and investment opportunity set (IOS) and inflation on dividend decision. Besides, to prove the effect of leverage, insider ownership, investment opportunity set (IOS) and inflation on firm value through the role of dividend decision mediation and to determine the direct effect of dividend policy on a value of the firm in the consumer goods industry sector.

\section{RESEARCH METHODS}

The population in this study are companies in the consumer goods industry sector listed on the IDX during the period 2010-2018. Total population of 53 companies, including the food and beverage sub-sector (26 issuers); cigarette subsector (4 issuers); pharmaceutical sub-sector (12 issuers); cosmetics sub-sector and household needs ( 6 issuers); household appliances subsector (4 issuers); and other consumer goods industry subsectors ( 1 issuer). The sampling method uses purposive sampling technique. The number of samples was 38 companies in the consumer goods industry sector. By using panel data, the amount of observation data is 342 data. 
Operational Definition and Variable Measurement: (a). Value of the firm is a measure of the total amount of total assets owned by a consumer goods industry sector. Value of the firm is proxied by Tobins'q, which was developed by James Tobin in 1967. Measurement scale with ratio scale. Tobin's Formulation Q (Berry, 2016):

Tobins' $^{\prime} q=\frac{\text { MVE }+ \text { DEBT }}{\text { TA }}$

(b). Dividend decision is proxied by the Dividend Payout Ratio (DPR) as a benchmark of cash dividends distributed by consumer goods industry sector. The DPR determines the amount of profit divided in the form of cash dividends and retained earnings as a source of funding. Measurement scale with ratio scale. The DPR (Wiagustini, 2010) formulation is as follows:

Dividend Payout Ratio $(D P R)=\frac{\text { Dividend per }- \text { share }}{\text { earnings per share }}$

(c). Leverage arises because companies in their operations use assets and sources of funds which create a permanent burden on companies in the consumer goods industry sector. In this study, leverage is proxied by Debt to Equity Ratio (DER). DER reflects the ability of companies in the consumer goods industry sector to fulfil all their obligations with their capital. Measurement scale with ratio scale. Alexandri (2008) in (Hasibuan et al., 2016), namely:

$D E R=\frac{\text { total debt }}{\text { total equity }}$

(d). Insider Ownership is a source of capital that comes from company owners. In managerial ownership accounting, records are determined by the number of shares owned managerially divided by the number of shares outstanding. According to Jumingan (2014), Insider Ownership formulation, namely:

Insider Ownership $(I O)=\frac{\text { (Directors 'Shares }+ \text { Commissioners' Shares })}{\text { Outstanding shares }}$

(e). Investment Opportunity Set (IOS) is proxied by the Market to Book Value of Assets (MBVA). MBVA reflects that the market assesses the return on investment in the consumer goods industry sector in the future from the expected return on its assets. The difference between market value and the book value of assets indicates a company's investment opportunity. Measurement scale with ratio scale. According to Amaech (2013), this variable is the most valid proxy.

$M B V A=\frac{\text { Market Capitalization }}{\text { Asset Book Value }}$

(f). Inflation is a condition where there is a sharp increase in prices that lasts continuously for an extended period. Inflation proxy is inflation sensitivity in companies in the consumer goods industry sector. Measurement scale with ratio scale. Measurement of inflation sensitivity adopts the research model of Djumahir (2007) with a linear regression equation.

$Y_{R S}=a+b_{\text {it }}$ inflation rate $+e_{t}$

Data normality test is used as one of the requirements to use multiple linear regression methods. According to Sofyan \& Heri (2014), this normality test aims to determine whether the data is normally distributed or not. This test uses the Kolmogorov Smirnov test with $\alpha=5 \%$. 
1. If $\alpha>0.05$, then the data is normally distributed

2. If $\alpha<0.05$, then the data is not normally distributed

The way to correct if there is a violation of the normality assumption is to change the regression model in the form of semi-log and double log (Ghozali, 2016). Path analysis aims to explain the direct and indirect effects of a set of variables as a causal variable to another set of variables that are due to variables (Ghozali, 2017). The path analysis model used in the study can be described in the following structural equations:

$Z=\beta X_{1 i} Z_{i}+\beta X_{22} Z_{i}+\beta X_{3 i} Z_{i}+\beta X_{4 i} Z_{i}+\varepsilon_{1 i}$
$Y=\beta X_{1 i} Y_{i}+\beta X_{2 i} Y_{i}+\beta X_{3 i} Y_{i}+\beta X_{4 i} Y_{i}+\beta Z_{i} Y_{i}+\varepsilon 2 i$

(Equation 1)

(Equation 2)

In the regression analysis, the test is based on the standard assumption of the least-squares method (OLS) to qualify as BLUE (Best Linear Unlimited Estimator). BLUE assumptions, among others, the absence of multicollinearity, and heteroskedasticity (Ghozali, 2016). (a) Multicollinearity test is done to test the relationship between some or all independent variables (independent variables) in a model. Multicollinearity can be detected by observing VIF within limits set by the researcher. In this study, multicollinearity occurs if VIF $>10$ or tolerance value $<0.10$. (b) Heteroscedasticity test is performed to test whether in a model, there is an inequality of variance from the residuals of observations to other observations. How to detect the existence of heteroscedasticity one of the formal methods is the Glejser test or Glejser test, namely by conducting a regression test of absolute residual values to the independent variable.

The Sobel test is carried out by testing the strength of the indirect effect of $X$ to $Y$ via $M$ (Mediation). The indirect effect of $X$ to $Y$ via $M$ is calculated by multiplying path a by path $\mathrm{M} \rightarrow \mathrm{Y}$ (b) or $\mathrm{ab}$. The standard error coefficients $\mathrm{a}$ and $\mathrm{b}$ are written with Sa and $\mathrm{Sb}$, and the magnitude of the standard error of the indirect effect (Indirect Effect) is Sat, calculated by the formula:

Sat $=\sqrt{ } b 2 s a 2+a 2 s b 2+s a 2 s b 2$

The test of significance of the indirect effect, it is necessary to calculate the $t$ value of the coefficient ab with the formula:

$t=\frac{a b}{s a b}$

$t$ count value compared to $t$ table value, if $t$ count value $>t$ table value, then it can be concluded that there is a mediating effect (Ghozali, 2017). The Kolmogorov-Smirnov test results show that all data in the study variable are normally distributed because all Asymp. values are variable. Sig. (2-tailed) is greater than 0.05 . Path analysis test results with $\alpha$ of $5 \%$ as follows:

Table 1. Test Results for the Direct Path.

\begin{tabular}{ccccc}
\hline $\begin{array}{c}\text { Variable } \\
\text { Independent }\end{array}$ & $\begin{array}{c}\text { Variable } \\
\text { Dependent }\end{array}$ & Beta $(\beta)$ & p-value & Explanation \\
\hline X1 & Z & $-0,176$ & 0,105 & Not Significant \\
X2 & Z & $-0,490$ & 0,031 & Significant \\
X3 & Z & $-0,217$ & 0,026 & Significant \\
X4 & Z & $-0,112$ & 0,069 & Not Significant \\
X1 & Y & $-0,230$ & 0,271 & Not Significant \\
X2 & Y & 0,072 & 0,036 & Significant \\
X3 & Y & 0,132 & 0,529 & Not Significant \\
X4 & Y & $-0,314$ & 0,030 & Significant \\
Z & Y & 0,363 & 0,047 & Significant \\
\hline
\end{tabular}


Table 1 shows insider ownership (X2) and IOS (X3) have a significant effect on Dividend decision (Z), but leverage (X1) and inflation (X4) have an insignificant effect. Furthermore, insider ownership (X2) and inflation (X4) has a significant effect on the value of the firm (Y), but leverage (X1) and IOS (X3) have no significant effect. On the other hand, Dividend decision (Z) also has a significant effect on the value of the firm (Y). Next, form the path diagram as follows:

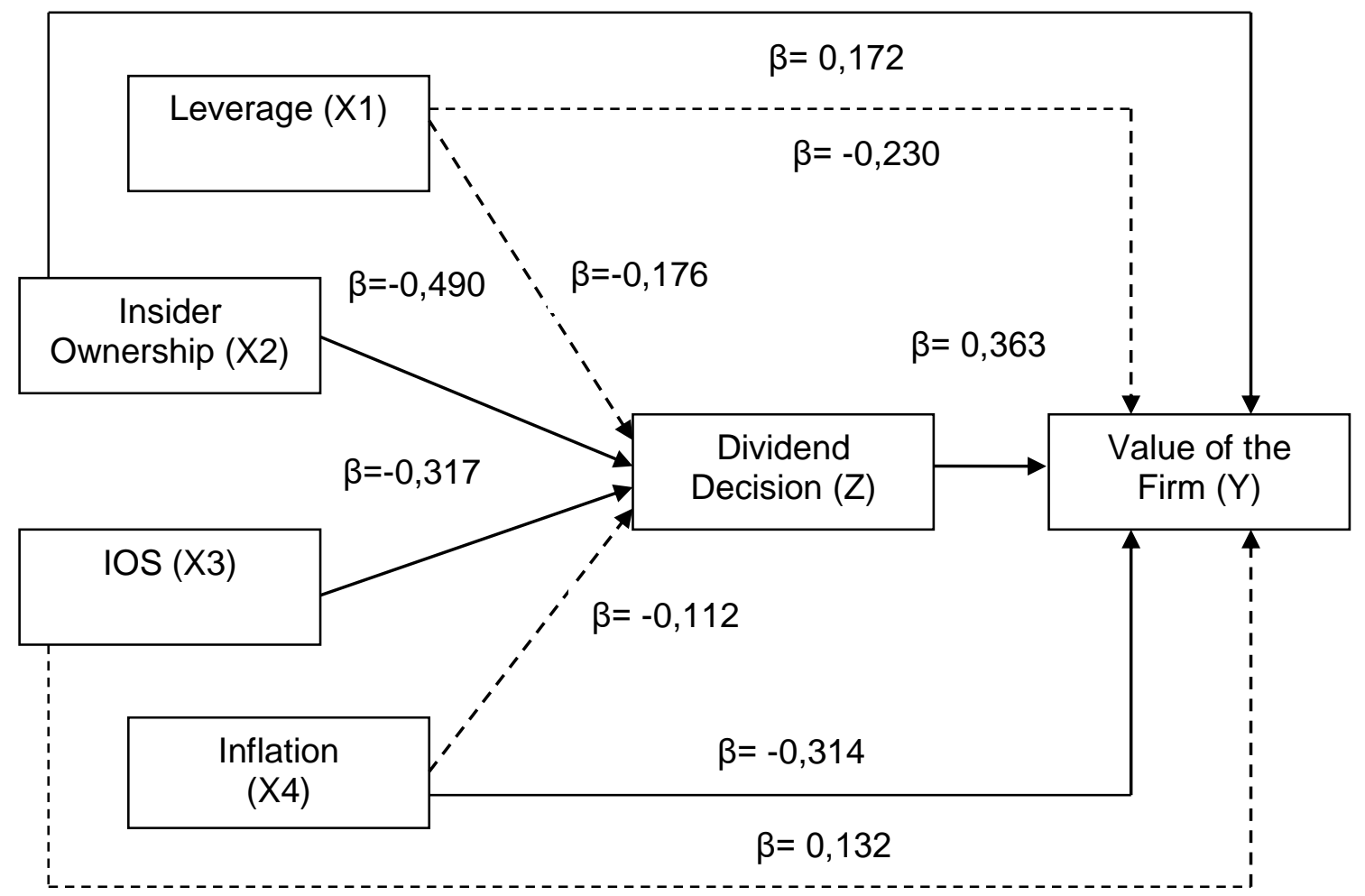

Figure 1. Path Analysis Model

Information:

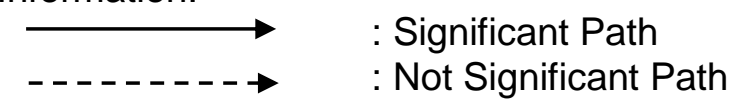

Based on Figure 1. Path diagram, the structural equation is formulated as follows:

$Z=-0,176 Z_{i} X_{1 i}-0,490 Z_{i} X_{2 i}-0,317 Z_{i} X_{3 i}-0,112 Z_{i} X_{4 i}+\varepsilon_{1 i}$

(Equation 3)

$Y=-0,230 Y_{i} X_{1 i}+0,172 Y_{i} X_{2 i}+0,132 Y_{i} X_{3 i}-0,314 Y_{i} X_{4 i}+0,363 Y_{i} Z_{i}+\varepsilon_{2 i} \quad$ (Equation 4)

In the regression analysis, it is necessary to test the classical assumptions based on the method of small squares (OLS) in order to qualify as BLUE (Best Linear Unlimited Estimator). The BLUE assumption, namely the absence of multicollinearity, and heteroskedasticity. (a) Multicollinearity test to test the relationship between some or all independent variables in a model.

Table 2. Multicollinearity Test (First Path)

\begin{tabular}{lcc}
\hline \multicolumn{1}{c}{ Variable } & Tolerance & Variance Inflation Factor \\
\hline Leverage (DER) & 0,639 & 1,564 \\
Insider Ownership (IO) & 0,608 & 1,644 \\
Investment Opportunity Set (IOS) & 0,858 & 1,166 \\
Inflation (Inflation Sensitivity/IS) & 0,909 & 1,101 \\
\hline
\end{tabular}

Table 2. Shows that, all independent variables have a value of Variance Inflation Factor (VIF) $<10$ and tolerance rates $>10 \%$, so it can be concluded that between 
independent variables multicollinearity does not occur.

Table 3. Multicollinearity Test Results (Second Path)

\begin{tabular}{lcc}
\hline \multicolumn{1}{c}{ Variable } & Tolerance & Variance Inflation Factor \\
\hline Leverage (DER) & 0,542 & 1,844 \\
Insider Ownership (IO) & 0,518 & 1,931 \\
Investment Opportunity Set (IOS) & 0,828 & 1,208 \\
Inflation (Inflation Sensitivity/IS) & 0,472 & 2,117 \\
Dividend Decision & 0,392 & 2,552 \\
\hline
\end{tabular}

Based on Table 3. It is known that all independent variables have a Variance Inflation Factor (VIF) value of $<10$ and a tolerance rate of $>10 \%$, so it can be concluded that there is no multicollinearity among independent variables.

Heteroscedasticity test is performed using the Glejser test on the first path regression model and produces the following equation:

ABSRES $_{i}=0,410-0,041 \mathrm{DER} i-0,0571 \mathrm{IO}_{i}+0,014 \mathrm{IOS}_{\mathrm{i}}-0,002 \mathrm{Sl}_{\mathrm{i}}+\mathrm{u}_{\mathrm{i}}$

$$
(0,056)^{\text {ts }} \quad(0,077)^{\text {ts }} \quad(0,998)^{\text {ts }} \quad(0,256)^{\text {ts }}
$$

Note: ${ }^{*}=$ significant at $(\alpha=5 \%)$, ts $=$ not significant

The equation above shows the independent variable is not significant to $\alpha$, meaning that the first equation regression model does not contain heteroscedasticity. The second equation and produces the following equation: ABSRES $_{2 i}=1,202-0,128 \mathrm{DER}_{i}-0,098 \mathrm{IO}_{i}-0,434 \mathrm{IOS}_{i}+0,003 \mathrm{Sl}_{i}-0,583 \mathrm{DPR} i+u_{i}$

$$
\begin{array}{llll}
(0,057)^{\text {ts }} & (0,217)^{\text {ts }} & (0,266)^{\text {ts }} & (0,677)^{\text {ts }} \quad(0,090)^{\text {ts }}
\end{array}
$$

Note: * significant at $(\alpha=5 \%)$, ts $=$ not significant

The second equation above shows that the independent variable is not significant to $\alpha$, meaning that the second equation does not contain heteroscedasticity. Path analysis examines the relationship of various alternative path variables from dividends, funding policies to the value of the firm. This analysis aims to find the path that most influences the results of this study. The alternative pathway consists of two alternatives. The following are calculations based on standardized regression weight.

Table 4. Standardized Regression Weight for Each Alternative Path

\begin{tabular}{lccc}
\hline \multicolumn{1}{c}{ Path } & Standardized Regression Weight & \\
\hline $\mathrm{IO} \rightarrow \mathrm{DPR} \rightarrow$ Value of The Form & $(-0,490)(0,363)$ & $=$ & $-0,17787$ \\
$\mathrm{IOS} \rightarrow \mathrm{DPR} \rightarrow$ Value of The Form & $(-0,317)(0,363)$ & $=$ & $-0,11507$ \\
& &
\end{tabular}

Table 5. Path Analysis Coefficient after Trimming

\begin{tabular}{ccccc}
\hline $\begin{array}{c}\text { Variable } \\
\text { Independent }\end{array}$ & $\begin{array}{c}\text { Variablel } \\
\text { Dependent }\end{array}$ & Beta $(\beta)$ & $p$-value & Explanation \\
\hline X2 & Z & $-0,172$ & 0,036 & Significant \\
X3 & Z & $-0,089$ & 0,027 & Significant \\
X2 & Y & 0,342 & 0,041 & Significant \\
X4 & Y & $-0,107$ & 0,033 & Significant \\
Z & Y & 0,205 & 0,040 & Significant \\
\hline
\end{tabular}

Based on the calculation of alternative lanes in Table 4, the number of insider ownership (IO) lines $\rightarrow$ DPR $\rightarrow$ value of the firm is the path that has the greatest value, meaning that the effect is greatest among the other lines. The results of the study showed that some paths were not significant, and then the paths that were not 
significant were removed from the Path Analysis model. For more details, here is a projected significant path.

Based on Table 5, the path analysis model after trimming theory is performed, shown in the following figure:

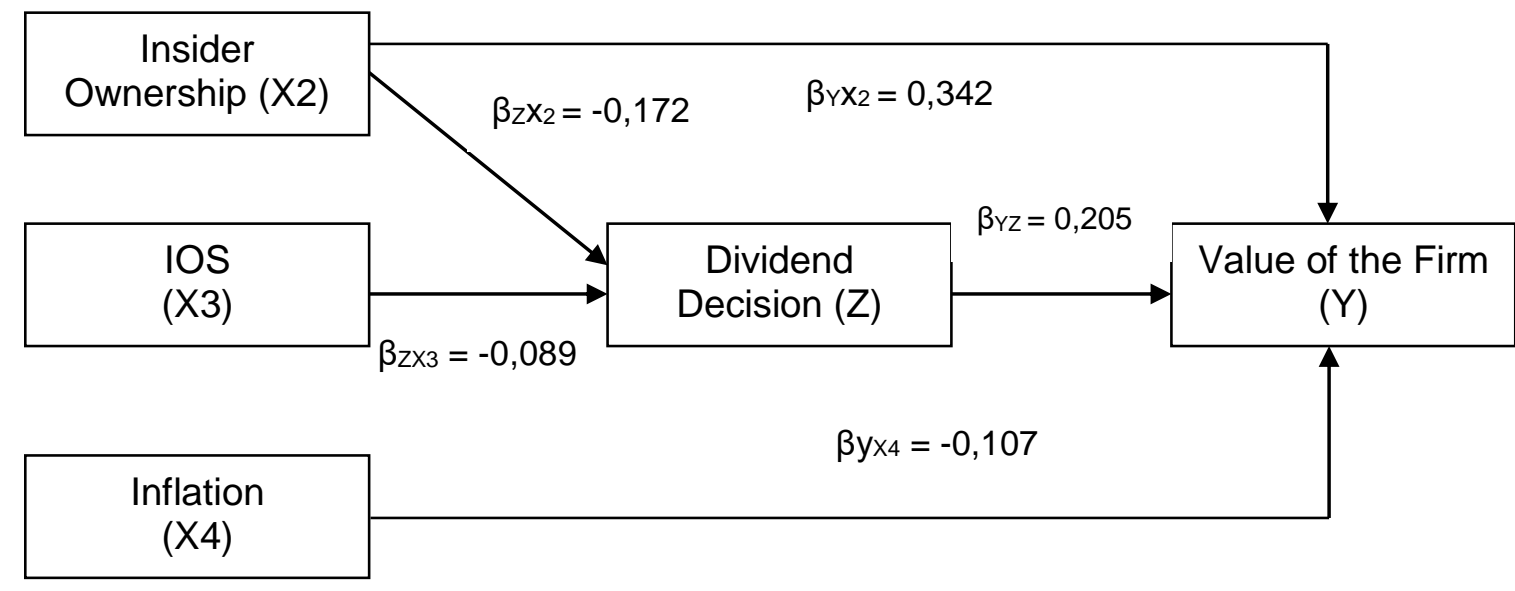

Figure 2. Model Path Analysis of Trimming Theory

Alternative path results of trimming presented calculations based on standardized regression weight.

Table 6. Standardized Regression Weight Trimming Results for Each Alternative Path

\begin{tabular}{lcl}
\hline Jalur & Standardized Regression Weight & \\
\hline & & \\
$\mathrm{IO} \rightarrow \mathrm{DPR} \rightarrow$ Value of the Firm & $(-0,172)(0,205)$ & $-0,03526$ \\
$\mathrm{IOS} \rightarrow \mathrm{DPR} \rightarrow$ Value of the Firm & $(-0,089)(0,205)$ & $=-0,01825$
\end{tabular}

Based on the calculation of alternative lines in Table 6 , the number of insider ownership (IO) lines $\rightarrow$ DPR $\rightarrow$ value of the firm is the path that has the highest value, meaning that the effect is most significant among the other lines.

The results of the mediation role test (dividend decision) of the relationship between insider ownership and the value of the company, showed a Sat of 0.0432 and t count of -3.685 , where t-count $>$ t-table $(5 \%)$ or $-3.658>1.96$ or with a p-value equal to 0.0269 which is below 0.05 . Next test the mediating role of the relationship between investment opportunity set (IOS) with the value of the company, showing a Sat of 0.0307 and $t$-value of -2.879 , where $t$-count $>$ t-table $(5 \%)$ or $-2.887>1.96$ or with a $p$ value equal to 0.0351 which is below 0.05 . In conclusion, dividend decision plays a significant role in mediating the relationship between insider ownership and investment opportunity sets with the corporate value of the consumer goods industry sector.

\section{RESULT AND DISCUSSIONS}

Effect of Leverage on Dividend decision. Test results show that leverage (DER) does not have a significant effect on Dividend decision (DPR). This condition explains that even though the company has debt, but the company can manage debt well, then the benefits of using debt will be higher on the costs. The results of this study are in line with the research of Marlina \& Danica (2009), which show that the Debt Equity Ratio (DER) variable has no significant effect on the DPR. However, contrary to research Arko et al. (2014) which shows the debt to equity ratio has a significant adverse effect on the dividend payout ratio.

Effect of Insider Ownership on Dividend decision. The results showed that insider 
ownership had a significant adverse effect on Dividend decision. The higher the percentage of shares owned by directors, management and commissioners or each party directly involved, the lower the opportunity for companies to pay dividends. Insider ownership prefers if company profits are not distributed to shareholders because they are used as internal capital used for company expansion. The results support Mangasih \& Asandimitra (2017) and Janah \& Azizah (2019) that insider ownership is significantly negatively related to Dividend decision, and relevant to agency theory that increasing insider ownership will reduce agency cost of equity if the company sets a Dividend decision.

Effect of Investment Opportunity Set (IOS) on Dividend decision. The results of the study showed that the Investment Opportunity Set (IOS) had a significant adverse effect on Dividend decision. The Implies of this result is that companies that have great investment opportunities will undoubtedly need substantial funds to finance the growth. So, they will reduce cash outflows, especially for cash dividends, because if not done, it will have an impact on extracting external funding sources. In increasing sales growth, companies need significant funds, which are funded from internal sources. A decrease in dividend payments causes companies to have an internal source of funds for investment purposes. Each company has an IOS that varies depending on the specific assets owned. The results of the study support Arko et al. (2014) that IOS has a significant adverse effect on the DPR variable. However, it does not support the research of Haryetti \& Ekayanti (2012), that IOS does not have a significant effect on Dividend decision.

Influence of Inflation on Dividend decision. The results showed that inflation had no significant effect on Dividend decision. This condition shows t possibility of inflation in the country is high; it may not affect the ability of companies to generate profits, because companies can deal with inflation well, one of which is the company is more focused on foreign markets (exports) than the domestic market. The results of this study support the research of Ardiyanti (2015) that inflation does not significantly influence Dividend decision.

Effect of Leverage on Value of the firm. The results of the study, that leverage (DER) has no significant effect on the value of the firm. The tradeoff theory explains that the higher the use of debt, the greater the benefits from the use of debt but the cost of bankruptcy and agency costs also increase even more significant. The results support the research of Mardiyati, (2012), that leverage has a positive but not significant effect on the value of the firm. Nevertheless, contrary to the results of the research, Hasibuan et al. (2016), that leverage affects the value of the firm.

Effect of Insider Ownership on Value of the firm. The results of this study, that insider ownership has a significant positive effect on the value of the firm. This condition provides an explanation that the higher insider ownership, the management tends to prioritize retained earnings to finance growth compared to dividend payments (cash outflow), so that the need for external funds with high costs and high risks can be reduced. The impact of this policy will undoubtedly increase the value of the company for investors in the future. The results of the study support the research of Supriyanah \& Ghoniyah (2015), that insider ownership has a significant positive effect on the value of the firm.

Effect of Investment Opportunity Set (IOS) on Value of the firm. The results of the study that the Investment Opportunity Set (IOS) has no significant effect on the value of the firm. The investment opportunity is the value of the company, which depends on the expenses. That has been determined by management in the future where at present it is still a choice of investment choices that are expected to produce higher returns, but the fact that macroeconomic conditions are not well predicted, causing 
that opportunity to be uncertain. The results of this study support Hariyono \& Lestari (2016) research finding that investment decisions (IOS) have no significant effect on the value of the firm.

Influence of Inflation on Value of the firm. The results of the study that inflation (inflation sensitivity) has a significant effect on the value of the firm. Inflation is a condition where an increase in prices that lasts continuously for an extended period. The price increase for companies that can manage costs efficiently, it becomes an opportunity. The results of this study support the research of Tandelilin (2010) and Egbunike \& Okerekeoti (2018) that inflation has a significant negative effect on the value of the firm (firm performance).

Effect of Dividend decision on Value of the firm. The results showed that the Dividend decision had a significant effect on the value of the firm. This condition explains companies that distribute high dividends will be responded positively by the market (investors) and vice versa so that prices will rise. In addition, dividends are considered less risky than capital gains. The research results are in line with the research findings of Supriyanah \& Ghoniyah (2015), Senata (2016), Berry (2016), and Oliver et al. (2016) that Dividend decision has a significant positive effect on the value of the firm. However, rejecting irrelevance theory proposed by Miller \& Modligiani (1961), Budagaga (2017), and Panchal (2018).

The Role of Dividend decision as Mediating Value of the firm. Significant test results of mediation variables signal the importance of the role of Dividend decision to increase the value of the firm. The optimal dividend decision is based on the goal of maximizing profits distributed to shareholders with the constraint of maximizing retained earnings for reinvestment as an internal source of funds Stewart C. Myers \& Majluf (1984). The results of Guizani, (2018), show that Dividend decision can mediate the relationship between insider ownership and company cash inflows. Besides, the Dividend decision gives a signal to profitability, reduces the risk of loss, and provides an opportunity for the company to grow (Yarram \& Dollery, 2015).

\section{CONCLUSSION}

Based on the results show that insider ownership and investment opportunity set (IOS) have a significant effect on Dividend decision. Nevertheless, leverage and inflation have no significant effect on Dividend decision. On the other hand, insider ownership and inflation have a significant effect on the value of the firm. However, leverage and investment opportunity set (IOS) has no significant effect on the value of the firm. Dividend decision has a significant positive effect on the value of the firm; (d) Dividend decision significantly plays a role in mediating the relationship between insider ownership and IOS with corporate value.

For further researchers, it is better to add other macroeconomic variables besides inflation, for example, exchange rates, interest rates or income. Also, the research time interval is extended, so that research results have a better contribution in building company value in the consumer goods industry sector.

\section{ACKNOWLEDGMENTS}

Feel free to impress your gratitude to person(s) that help you in accomplish the research. Please keep the paragraph not more than 200 words.

\section{REFERENCES}

Al Najjar, B. (2012). Dividends Behavior and Smoothing New Evidence from Jordanian Panel Data. University of the West England.

Allen, F., Bernardo, A. E., \& Welch, I. (2000). A Theory of Dividends Based on Tax Clienteles. 
Journal of Finance, 55(6), 2499 - 2536.

Amaech, E. P. (2013). Application of computed financial ratios in fraud detection modelling: a study of selected banks in Nigeria. Asian Economic and Financial Review, 3(11), 1405-1418.

Amidu, M. (2007). How does dividend policy affect the performance of the firm on Ghana Stock Exchange?. Investment Management and Financial Innovations, 4(2), 103-112.

Ardiyanti, N. R. S. A. (2015). Pengaruh Faktor-Faktor Fundamental dan Teknikal terhadap Dividend Payout Ratio. Jurnal Riset Akuntansi Dan Perpajakan, 2(2), 218-229.

Arko, C. A., Abor, J., Adjasi, K. D. C., \& Amidu, M. (2014). What Influence Dividend Decisions of Firms in Sub-Saharan African?. Journal of Accounting in Emerging Economics, 4(1), 57-78.

Baker, M., Wurger, J. (2004). A Catering Theory of Dividends. Journal of Finance, 59(3), 1125 $-1165$.

Berry, Y. (2016). Hubungan Kebijakan Dividen dan Nilai Perusahaan Pada Tahap Mature dan Growth. JRAK, 7(1), 65-73.

Bhattacharya, S. (1979). Imperfect Information, Dividend Policy, and "the bird in the hand" fallacy. Bell Journal of Economics, 10(2), $259-270$.

Bisnis.com. (2017). Saham-saham Consumer Kian Diminati Investor. Retrieved from https://Www.Bisnis.Com/Amp//Read/20170303/190/633538/.

Boyd, J., Jagannathan, R. (1994). Ex-Dividend Price Behavior of Common Stocks: Fitting Some Pieces of the Puzzle. Review of Financial Studies, 7(4), 711-741.

Brigham, E. F., Houston, J. F. (2011). Dasar-Dasar Manajemen Keuangan (11th ed.). Salemba Empat.

Budagaga, A. (2017). Dividend Payment and its Impact on the Value of Firms Listed on Istanbul Stock Exchange: A Residual Income Approach. International Journal of Economics and Financial Issues, 7(2), 370-376.

Djumahir. (2007). Pengaruh Variabel-variabel Mikro dan Variabel-variabel Makro terhadap Financial Distress Pada Perusahaan Industri Food and Beverages yang Terdaftar di Bursa Efek Jakarta. Jurnal Aplikasi Manajemen, 5(3), 484-492.

Egbunike, C. F., Okerekeoti, C. U. (2018). Macroeconomic factors, firm Characteristics and Financial Performance: A Study of Selected Quoted Manufacturing Firms in Nigeria. Asian Jurnal of Accounting Research, 3(2). doi: https://doi.org/https://doi.org/10.1108/AJAR-09-2018-0029

Fama, E., Babiak, H. (1968). Dividend Policy: An Empirical Analysis. Journal of the American Statistical Association, 63(324), 1132 - 1161.

Fidhayatin, S. K., Dewi, N. (2012). Analisis nilai perusahaan, kinerja perusahaan dan Kesempatan bertumbuh perusahaan terhadap return Saham pada perusahaan manufaktur yang listing di BEl. The Indonesian Accounting Review, 2(2), 203-214.

Ghozali, I. (2016). Aplikasi Analisis Multivariate dengan Program IBM SPSS 23 (VIII). Badan Penerbit Universitas Diponegoro.

Ghozali, I. (2017). Model Persamaan Struktural Konsep dan Aplikasi dengan Program AMOS 24 (7th ed.). Badan Penerbit Universitas Diponegoro.

Gordon, M. (1961). The Investment, Financing, and Valuation of Corporation. Review of Economics and Statistics.

Guizani, M. (2018). The mediating effect of Dividend Payout on the Relationship Between Internal Governance and Free Cash Flow. Corporate Governance International Journal of Business in Society, 1-25. doi: https://doi.org/https://doi.org/10.1108/CG-01-20180011

Hariyono, M. S., Lestari, P. L. (2016). Pengaruh Struktur Kepemilikan, IOS, dan ROI terhadap Nilai Perusahaan Pada Perusahaan Food and Beverage. E-Jurnal Manajemen Unud, 4(4), 1599-1626.

Harmono. (2014). Manajemen Keuangan Berbasis Balanced Scorecard Pendekatan Teori, Kasus dan Riset Bisnis. PT. Bumi Aksara.

Haruman, T. (2008). Pengaruh Struktur Kepemilikan terhadap Keputusan Pendanaan (Prespektif Agency Theory) Survey Pada Perusahaan Manufaktur di PT. Bursa Efek 
Indonesia. National Conference on Management Research.

Haryetti, Ekayanti, R. (2012). Pengaruh Profitabilitas, Investment Opportunity Set dan Pertumbuhan Perusahaan Terhadap Kebijakan Dividen Pada Perusahaan LQ-45 yang Terdaftar di BEl. Jurnal Ekonomi, 20(3), 1-18.

Hasibuan, V., Dzulkirom, M, A., Endang, N. N. (2016). Pengaruh Leverage dan Profitabilitas Terhadap Nilai Perusahaan (Studi pada Perusahaan Property dan Real Estate yang Terdaftar di Bursa Efek Indonesia Periode Tahun 2012-2015. Jurnal Administrasi Bisnis, 39(1), 139-147.

Janah, S. S., Azizah, D. F. (2019). Pengaruh Insider Ownership, Institutional Ownership, Collateralizable Assets dan Debt to Total Assets Terhadap Dividend Payout Ratio. (Studi pada Perusahaan non-Keuangan yang Terdaftar di Bursa Efek Indonesia (BEI) Periode 2015-2017. Jurnal Administrasi Bisnis (JAB), 74(1), 19-29.

Jumingan. (2014). Analisis Laporan Keuangan. PT. Bumi Aksara.

Kighir, A. E., Omar, N. H., Mohamed, N. (2015). Corporate Cash Flow and Dividends Smoothing: a panel data Analysis at Bursa Malaysia. Journal of Financial Reporting and Accounting, 13(1), 2-19.

Kontan.co.id. (2012). Sektor Barang Konsumsi Dan Perbankan Bisa Jadi Andalan Di 2012. Retrieved from http://Kontan.Co.Id/New.

Lintner, J. (1956). Distribution of Income of Corporations Among Dividends, Retained Earnings, and Taxes. American Economic Review., 46(2), 97-113.

Litzenberger, R. H., Ramaswamy, K. (1982). The Effects of Dividends on Common Stock Prices Tax Effects or Information Effects. Journal of Finance, 37(2), 429 - 443.

Mangasih, Asandimitra. (2017). Pengaruh Insider Ownership, Institutional Ownership, Dispersion of Ownership, Collateralizable Assets, dan Board Independence Terhadap Kebijakan Dividen Pada Sektor Finance Periode 2011-2015. Jurnal IImu Manajemen, $5(3), 12-23$.

Mardiyati, U. (2012). Pengaruh Kebijakan Dividen, Kebijakan Hutang, dan Profitabilitas Terhadap Nilai Perusahaan Manufaktur Yang Terdaftar Di Bursa Efek Indonesia Periode 2005-2001. Jurnal Riset Manajemen Sains Indonesia, 3(1), 1-16.

Marlina, L., Danica, C. (2009). Analisis Pengaruh Cash Position, Debt to Equity Ratio dan Return on Assets Terhadap Dividend Payout Ratio. Jurnal Manajemen Bisnis, 2(1), 16.

Miller, M., Modligiani, F. (1961). Dividend Policy, Growth and The Valuation of Shares. Journal of Business, 34, 411-433.

Munthe, K., Hotmauli, S. (2018). Pengaruh Inflasi, Suku Bunga dan Nilai Tukar Terhadap Return Saham Pada Perusahaan Manufaktur di Bursa Efek Indonesia Pada Periode 2013 - 2016. Jurnal Manajemen Dan Bisnis, 18(2), 101-113.

Myers, S. C. (1977). The determinant of Corporate Borrowing. Journal of Financial Economics, 9(3), 237-264.

Myers, Stewart C., Majluf, N. S. (1984). Corporate financing and investment decisions when firms have information that investors do not have. Journal of Financial Economics, 13(2), 187-221. doi: https://doi.org/10.1016/0304-405X(84)90023-0

Oliver, E. C., Iniviei, E. S., Daniel, E. S. (2016). Effect of Dividend Policy on the Value of Firms (Empirical Study of Quoted Firms in Nigeria Stock Exchange). Research Journal of Finance and Accounting, 7(3), 17-24.

Panchal, N. (2018). How does Dividend Policy Impact the Value of the Firm? - An analysis of Selected Indian Sectors. ASEAN Journal of Management, 9(1), 99-106.

Petitt, R. R. (1977). Taxes, Transactions Costs and the Clientele Effect of Dividends. Journal of Financial Economics, 5, 89-96.

Rozeff, M. S. (1982). Growth, Beta and Agency Costs as Determinants of Dividend Payout Ratios. Journal of Financial Research, 5(3), 249-259.

Senata, M. (2016). Pengaruh Kebijakan Dividen Terhadap Nilai Perusahaan yang tercatat pada Indeks LQ-45 Bursa Efek Indonesia. Jurnal Wira Ekonomi Mikriskil, 6(1), 42-56.

Sofyan, Heri. (2014). SPSS Complete. Salemba Infotek.

Sofyaningsih, Hardiningsih. (2011). Struktur Kepemilikan, Kebijakan Dividen, Kebijakan Utang 
dan Nilai Perusahaan. Jurnal Dinamika Keuangan Dan Perbankan, 3(1), 58-67.

Supriyanah, Ghoniyah, N. (2015). Kebijakan Pendanaan, Insider Ownership dan Firm Size terhadap Nilai Perusahaan yang Listed di Bursa Efek Indonesia (BEI) Tahun 20102013. Ekonomi Bisnis, 16(1), 68-79.

Syamsuddin, L. (2011). Manajemen Keuangan Perusahaan. Rajawali Pers.

Tandelilin, E. (2010). Portfolio dan Investasi: Teori dan Aplikasi (1st ed.). Kanisius.

Walter, J. E. (1963). Dividend Policy: Its Influence on the Value of the Enterprise. Journal of Finance, 12(2), 280-291.

Watts, R. (1973). The Information Content of Dividends. Journal of Business, 46(2), 191-211.

Wiagustini, N. P. (2010). Dasar-Dasar Manajemen Keuangan. Udayana University Press.

Yarram, S. R., Dollery, B. (2015). Corporate Governance and Financial Policies. Managerial Finance, 41(3), 267-285. 